\title{
Management of Xanthomonas fragariae with Pre- and Postharvest Treatments to Overcome Trade Barriers for California Strawberries
}

\author{
Stacey E. Haack, ${ }^{1}$ Spencer S. Walse, ${ }^{2}$ Kevin Nguyen, ${ }^{1}$ and James E. Adaskaveg, ${ }^{1, \dagger}$ \\ ${ }^{1}$ Department of Microbiology and Plant Pathology, University of California, Riverside, CA 92521; and ${ }^{2}$ San Joaquin Valley \\ Agricultural Sciences Center, United States Department of Agriculture, Agricultural Research Service, Parlier, CA 93648
}

\begin{abstract}
Xanthomonas fragariae, the causal agent of angular leaf spot (ALS) of strawberry, is a quarantine pathogen in some export markets, causing trade restrictions and economic loss to the California fresh-market strawberry industry. Preharvest chemical management options are limited to copper, and there are no postharvest treatments available that reduce populations of the pathogen if ALS is detected at an export destination. Here, we report high preharvest efficacy for the experimental bactericide amino thiadiazole and the commercial product zinc thiadiazole, alone and in mixtures with low rates of copper or the antibiotic kasugamycin, with average disease incidence reduction of up to $92.8 \%$ compared with the control. Although effective against quarantine insect pests of strawberry, postharvest methyl bromide fumigation was ineffective against $X$. fragariae in diseased plant tissue at a standard commercial rate. Postharvest

propylene oxide fumigation, used for decades by the California nut industries for insect and microbial disinfestation, significantly reduced $X$. fragariae populations in infected leaflet tissues by at least 2.5 -log compared with controls at a dose of $\geq 142 \mu \mathrm{g} / \mathrm{ml}$ for $2 \mathrm{~h}$ at 15 to $20^{\circ} \mathrm{C}$. Fumigated leaflets showed little to no phytotoxicity at effective rates, and fumigated fruit were not significantly affected in appearance or susceptibility to postharvest gray mold or Rhizopus rot following storage at $2^{\circ} \mathrm{C}$ for 3 days and at $15^{\circ} \mathrm{C}$ for an additional 5 days. Together, these new treatments offer potential strategies for establishing a systems approach with preharvest treatments significantly reducing the risk of ALS on plants and, in response to quarantine detections, a postharvest fumigation treatment that reduces viable pathogen populations in existing lesions.
\end{abstract}

Angular leaf spot (ALS), caused by Xanthomonas fragariae Kennedy and King, is the most economically important bacterial disease of strawberry (Kennedy and King 1962a; Maas 1998). Characteristic symptoms include angular, water-soaked lesions 1 to $4 \mathrm{~mm}$ in diameter that are translucent when viewed using transmitted light and dark green when viewed using reflected light (Kennedy and King 1962a). Lesions may later coalesce, causing reddish spots on the upper side of leaves that eventually become necrotic (Gubler et al. 2005). All plant tissues are susceptible to infection, including leaves, stems, crowns, sepals, and calyxes (Gubler et al. 1999; Maas 1998). Calyx infections will occasionally extend into the pedicel, causing blight of the associated flower tissues (Gubler et al. 1999). The bacterium previously was shown to move systemically within the plant's vascular system and may cause collapse in extreme infections (Bestfleisch et al. 2015; Hildebrand et al. 1967; Milholland et al. 1996); however, Wang et al. (2018) using green fluorescent protein-labeled bacteria concluded that systemic movement was limited and appeared to be a passive process.

$X$. fragariae is not free-living in soil but is able to survive between growing seasons on infected plant debris (Kennedy and King 1962b; Roberts et al. 1996). Pathogen populations can be reduced to low levels by preplant fumigation with methyl bromide/chloropicrin mixtures (Gubler et al. 2005). Disease outbreaks still may occur in fumigated fields due to planting of infected nursery stock. Therefore, the main preplant strategy of ALS management is the use of diseasefree planting material (Gubler et al. 2005; Roberts et al. 1997; Zimmermann et al. 2004). Transplants that appear healthy, however,

${ }^{\dagger}$ Corresponding author: J. E. Adaskaveg; jim.adaskaveg@ucr.edu

Funding: The authors thank the California Strawberry Commission and the Federal Technical Assistance for Specialty Crops (TASC) fund for financial support of this project.

The author(s) declare no conflict of interest.

Accepted for publication 19 January 2019.

() 2019 The American Phytopathological Society may contain latent, asymptomatic infections that become activated once conditions are favorable (Mahuku and Goodwin 1997; Turechek and Peres 2009). Lesions exude bacterial ooze that is disseminated short distances by splashing water (Kennedy and King 1962b). In the low-rainfall California climate, this within-field pathogen spread is exacerbated by overhead irrigation that is applied throughout the growing season in nursery production and in early plant establishment for fruit production (Daugovish et al. 2009). Although ALS occurs at a wide range of temperatures, development is generally favored by cool, moist days with cold nights near freezing (Maas 1998).

Chemical treatments applied during the growing season are considered only marginally effective against $X$. fragariae (Gubler et al. 2005). Thus, if the pathogen is introduced in the field, in-season management relies heavily on avoiding favorable, wet microclimate environments by using drip or subsurface irrigation. Copper-containing products are registered and are used especially in nursery transplant production, but additional modes of action with high efficacy are needed to develop bactericide rotation programs and resistance management strategies.

Thiadiazole-derived compounds have potential applications as antimicrobials in agriculture (Frija et al. 2016; Hu et al. 2014). In preliminary laboratory assays, technical-grade amino thiadiazole (ATD) and commercial-grade zinc thiazole, or more accurately zinc thiadiazole (ZTD), were inhibitory against $X$. arboricola pvs. pruni and juglandis, causal agents of bacterial spot of almond and walnut blight, respectively (J. E. Adaskaveg, unpublished). A $20 \%$ formulation of ZTD is registered in China for agricultural use. The antibiotic kasugamycin was recently registered for use against Erwinia amylovora, causal agent of fire blight of pome fruits and other rosaceous plants, federally (2014) and in California (2018), and against walnut blight and bacterial blast and canker (Pseudomonas syringae pv. syringae) of sweet cherry in 2018 federally and in California. These compounds show potential for evaluation and registration, offering additional tools for preharvest management of ALS in California.

Yield losses due to ALS can be high, especially in the southeastern United States, where wet environmental conditions are favorable for disease development. In California, Florida, and other states, however, the disease is primarily of regulatory concern because $X$. fragariae is designated a quarantine pathogen in some countries 
(EPPO 1997; Turechek and Peres 2009). Detection of viable $X$. fragariae in calyxes of fruit destined for high-value export markets has caused quarantine restrictions, trade losses, and market closures. Specifically, Australia was a market for California strawberry fruit in 2010 and 2011 with an export volume of 150,000 to 200,000 boxes annually with an estimated current value of approximately $\$ 10$ million (California Strawberry Commission, personal communication). Australian government officials repeatedly detected viable $X$. fragariae in ALS lesions on calyxes of fresh-market fruit in 2010 during routine import inspections and again in 2011 during a preclearance program (AGDA 2018; AQIS 2011). When quarantine insect pests are detected, infested shipments can be fumigated at the ports, reinspected, and allowed to be imported once disinfested. Because there is no postharvest curative treatment to eradicate $X$. fragariae and because of the high cost of rerouting the highly perishable crop to alternative lower-value markets, shipments to Australia were considered high-risk and were suspended in 2012 by the California strawberry industry.

In postharvest fumigation against insect pests for quarantine purposes, methyl bromide is still permitted on several fresh-market crops, including strawberries (Federal Register 2003). Several other fumigation compounds are also registered or under evaluation (Heather and Hallman 2007; USDA 2010). Propylene oxide (PPO) was identified as a fumigant of interest for evaluation against ALS owing to its registration for more than 40 years and its use in the California nut industries for insect and microbial control (U.S. EPA 2006). PPO is an alkylating agent that reacts with cellular macromolecules including DNA, resulting in cell death (Sweeney et al. 2009).

The purpose of this research was to evaluate new management options for ALS with an overall goal of reducing the presence of $X$. fragariae on calyxes of fresh-market strawberry fruit. Trade regulation and mitigation are intricately dependent on pre- and postharvest management strategies in a systems approach to reduce the risk of pest or disease occurrence on the crop. Our specific preharvest management objective was to evaluate the efficacy of ATD, ZTD, and kasugamycin using selected rates and mixtures compared with copper against ALS on strawberry plants. Postharvest management objectives were to (i) evaluate the efficacy of PPO fumigation in reducing viable $X$. fragariae cells in infected leaf tissue, (ii) evaluate phytotoxic effects of PPO fumigation on strawberry fruit tissues, and (iii) investigate effects of PPO fumigation on susceptibility to the important postharvest fungal pathogens Rhizopus stolonifer and Botrytis cinerea.

\section{Materials and Methods}

Bacterial strain and culturing. $X$. fragariae (strain $X f 1298$, original designation $F a \mathrm{P} 21$ ) was obtained from ALS-symptomatic 'Portola' strawberry plants from a Northern California nursery in December 2011 by John Leveau at the University of California, Davis, using described methods (Henry et al. 2016). For all experimentation, $X f 1298$ was regrown from long-term storage at $-80^{\circ} \mathrm{C}$ in $20 \%$ glycerol and plated onto Wilbrink's medium with nitrate (WBN) agar (EPPO 2006; Koike 1965). After 3 to 4 days of growth at $25^{\circ} \mathrm{C}$, colonies were subcultured and allowed to grow for an additional 3 to 4 days. A bacterial suspension in sterile deionized water was adjusted to approximately $1 \times 10^{7}$ cells $/ \mathrm{ml}\left(70 \% \mathrm{OD}_{600}\right.$ transmission) and used immediately for inoculations. $X f 1298$ sensitivity to copper was evaluated using WBN agar amended with copper sulfate to final concentrations of 0 (control), 10,20 , or $30 \mu \mathrm{g} / \mathrm{ml}$ of metallic copper equivalent (MCE). Ten microliters of bacterial suspension was streaked radially in duplicates onto three replicated plates using a sterile pestle. Growth was evaluated after 3 days of incubation at $25^{\circ} \mathrm{C}$ and compared with the control.

Plant inoculation. Bare-root 'Splendor' (Plant Sciences, Watsonville, CA) strawberry plugs were stored at $2^{\circ} \mathrm{C}$ for up to 4 months prior to planting in $10 \times 10 \times 10 \mathrm{~cm}$ pots and maintained in a greenhouse at 22 to $27^{\circ} \mathrm{C}$ at the University of California, Riverside (UCR). Plants were fertilized using 14-14-14 slow-release fertilizer at a rate of approximately 4 g/pot (Osmocote Classic; Everris North America, Dublin, $\mathrm{OH}$ ), which was applied to the soil surface following planting, drip-irrigated daily, and treated with foliar insecticides/ miticides approximately every 2 to 3 weeks. Leaf undersides of plants with at least three mature leaves were inoculated with the bacterial suspension using an atomizer (DeVilbiss 15-RD; Sunrise Medical, Somerset, PA). Leaves were sprayed until a film of small droplets was visible, just before run-off. Plants were then moved into a bench-top chamber $(3.3 \times 2 \times 1 \mathrm{~m})$ with clear plastic tarping. Inside the chamber, six upward-facing misters $(30 \mathrm{ml} / \mathrm{min} / \mathrm{mister})$ mounted approximately $60 \mathrm{~cm}$ above the pots were operated twice daily for $1 \mathrm{~min}$ to provide leaf wetness and high relative humidity (RH) (Hildebrand et al. 2005). After 5 days, plants were moved to greenhouse benches. ALS infection was confirmed for each inoculation by reisolation and pathogen identification techniques described below. Infected tissues were used for fumigation tests within 6 weeks of inoculation.

Bactericides. Copper hydroxide (Kocide 3000; DuPont, Wilmington, DE) or a premixture of copper hydroxide and copper oxychloride (Badge X2; Gowan Co., Yuma, AZ), kasugamycin (Kasumin 2L; Arysta LifeScience, Cary, NC), technical-grade thiadiazole (5-amino-1,3,4-thiadiazole-2-thiol [ATD]; Sigma Aldrich, St. Louis, MO), and a $20 \%$ commercial formulation of ZTD (5-amino-1,3,4thiadiazole-2-thiol zinc salt [2:1]) (Zhejiang Xinnong Chemical Co., Ltd., Hangzhou, China) were used by themselves or in selected mixtures at rates indicated in Figures 1 and 2. ATD $(0.5 \mathrm{~g})$ was first dissolved in a mixture of $1.35 \mathrm{ml}$ of dimethyl sulfoxide and $5.4 \mathrm{ml}$ of $95 \%$ ethanol before diluting with water. Formulated compounds were mixed directly in water and used immediately.

Efficacy of preharvest bactericide applications to manage ALS in greenhouse studies. In each of the three or two repeated trials for the first or second experiment, respectively, bactericides were applied to all aboveground plant surfaces using a handheld spray bottle until run-off. Controls were sprayed with water. After $12 \mathrm{~h}$ of drying, plants were inoculated as described above. Plants were arranged in a randomized complete block design with five to six blocks of singleplant replications. After 14 to 20 days, each fully expanded, treated leaf was evaluated for the presence of ALS. Disease incidence was based on the number of leaves with at least one lesion of the total number of leaves treated per replication, and relative disease incidence $=$ disease incidence in a treatment $/$ mean incidence of the

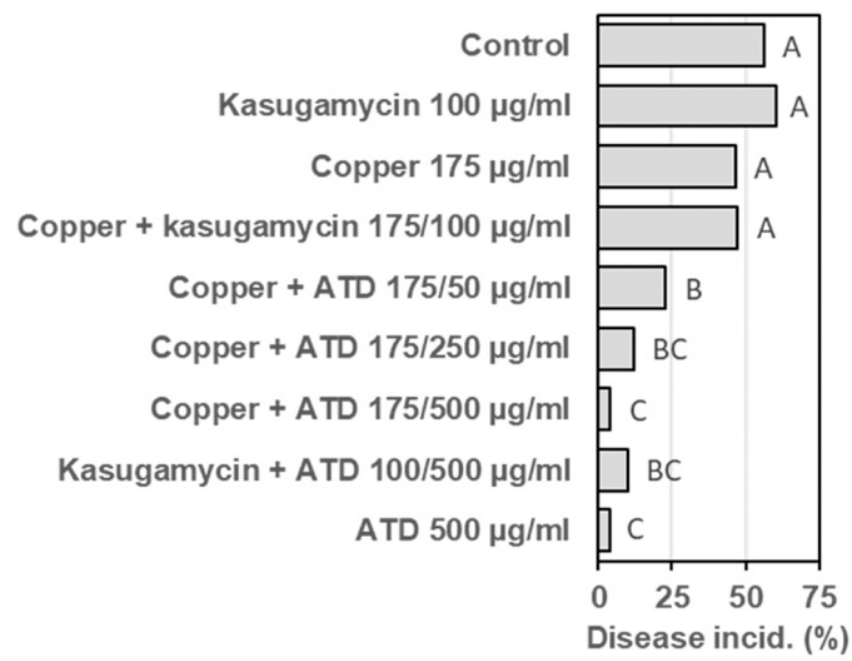

Fig. 1. Efficacy of foliar bactericide treatments on incidence of angular leaf spot (ALS) of strawberry in greenhouse studies. Plants were treated, air dried, inoculated with a bacterial suspension, and rated after 14 to 20 days. Incidence of disease is based on the number of leaves with ALS lesions of the total number of leaves. Values are the mean of three experiments. Bars followed by the same letter are not significantly different as denoted by the Ismeans statement of the GLIMMIX procedure in SAS version 9.4 at the $5 \%$ level of significance. Copper rates are based on metallic copper equivalent. In the first experiment, copper hydroxide was used, and in the second and third experiments, a mixture of copper hydroxide and copper oxychloride was used. ATD = amino thiadiazole. 
control treatment $\times 100$. In the second experiment, number of lesions per leaf was also recorded. Relative lesion number was calculated as the number of lesions per leaf in a treatment/mean number of lesions per leaf in the control $\times 100$.

For the three repeated trials of the first experiment, treatments and inoculations were done October 10, 2014, July 24, 2015, or August 14, 2015, and evaluations were on October 30, 2014, August 7, 2015, or September 1, 2015, respectively. For the two repeated trials of the second experiment, treatments and inoculations were done May 14 or June 11, 2018, and evaluations were on June 4 or June 25, respectively.

Methyl bromide fumigation of plant material with ALS symptoms. Infected leaflets were grouped so that each treatment unit contained leaflets with approximately similar disease severity. The first fumigation trial was performed on July 16, 2014, at the USDA Parlier, CA, facility using the exploratory fumigation methods of Walse et al. (2016). Twelve leaflets were treated with $35 \mu \mathrm{g} / \mathrm{ml}$ of methyl bromide for $3 \mathrm{~h}$ at 12.7 or $15.6^{\circ} \mathrm{C}$. Control leaflets were placed into a chamber at $15.6^{\circ} \mathrm{C}$ but did not receive any fumigant, placed on the counter-top at the same temperature, or kept at $2.0 \pm 0.5^{\circ} \mathrm{C}$. The second study was conducted among commercial strawberry fruit that were destined for export at a fumigation facility in Watsonville, CA, on July 22, 2014. For this, six leaflets each were placed among the fruit load at five locations in the chamber $(2.3 \times$ $2.3 \times 6 \mathrm{~m}$ ), resulting in a total of 30 treated leaflets. The fruit and leaflets were commercially treated with methyl bromide (Cardinal Professional Products, Hollister, CA) for the control of quarantine mite insects, at an applied rate of approximately $1,362 \mathrm{~g} /$ chamber $(43.9 \mu \mathrm{g} / \mathrm{ml})$, equaling an approximate target dose of $35 \mu \mathrm{g} / \mathrm{ml}$, accounting for sorption (Walse et al. 2013, 2016). After $3 \mathrm{~h}$ of fumigation at 18 to $26^{\circ} \mathrm{C}$ and a 2 -h venting period, leaflets were collected, and bacterial isolations were conducted as described below. Control leaflets $(n=12)$ were not exposed to the fumigant but were set on a counter outside of the fumigation chamber for the duration of treatment period.

PPO fumigation of plant material with ALS symptoms. Infected leaflets were sorted visually according to disease severity as described above and acclimated to the appropriate fumigation temperature for 4 to $12 \mathrm{~h}$ prior to treatment. Fumigant concentrations are indicated in Figures 3 and 4. In three laboratory tests at UCR using static chambers, leaflets were placed inside 1-liter glass jars containing a $25-\mathrm{ml}$ glass vial. Appropriate volumes of PPO fumigant were loaded into the inner vial, and glass jars were closed immediately with a rubber-sealed lid and incubated at $15^{\circ} \mathrm{C}$ (trials 2 and 3) or $20^{\circ} \mathrm{C}$ (all trials). Control jars received no fumigant. After $2 \mathrm{~h}$, jars were opened and vented for $30 \mathrm{~min}$ in a fume hood. There were three replicate jars per treatment unit, each with three or four leaflets.

In laboratory trials at USDA Parlier, leaflets were placed inside 28-liter, modified vacuum chambers (Labconco Corp., Kansas City,
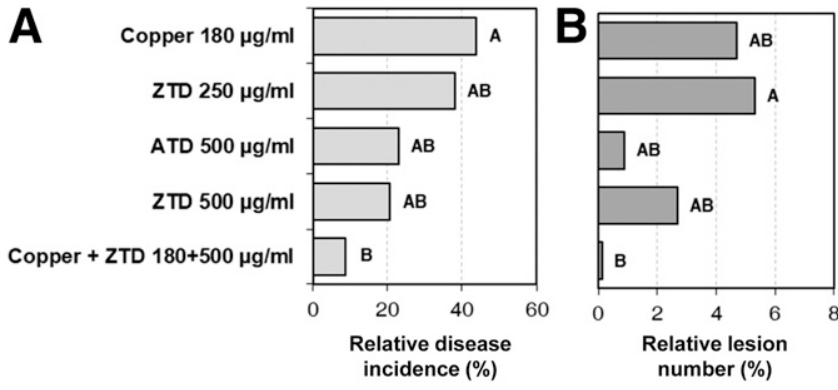

Fig. 2. Efficacy of foliar bactericide treatments on incidence (A) and severity (B) of angular leaf spot (ALS) of strawberry in greenhouse studies. Plants were treated, air dried, inoculated with a bacterial suspension, and rated after 14 to 20 days. Relative disease incidence and lesion number are based on the mean values for the control $(=100 \%)$. Bars followed by the same letter are not significantly different as denoted by the Ismeans statement of the GLIMMIX procedure in SAS version 9.4 at the $5 \%$ level of significance. ATD = amino thiadiazole, and ZTD = zinc thiadiazole.
MO) with multiple ports for evacuation, air sampling, and fumigant introduction as described previously (USDA 2010; Walse et al. 2016). The chambers were located inside a walk-in environmental incubator maintained at $15^{\circ} \mathrm{C}$ (USDA 2010). Nine to 12 leaflets were placed inside perforated stainless-steel baskets. Doses required to achieve target PPO fumigation concentrations were calculated for
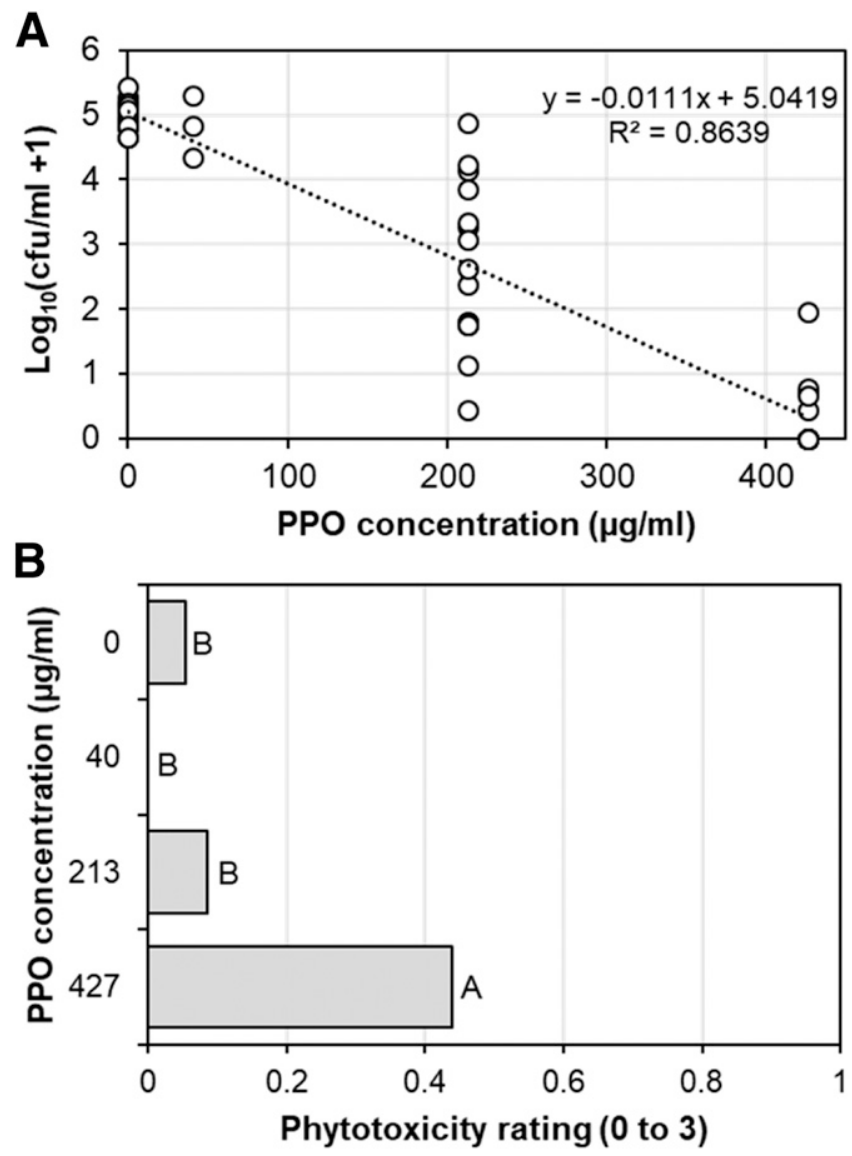

Fig. 3. A, Regression of propylene oxide (PPO) concentration applied to diseased strawberry leaflets in a static fumigation chamber on Xanthomonas fragariae populations recovered in three trials. Each open circle represents the average bacterial population recovered from leaflets in a single chamber replicate. $\mathbf{B}$, Phytotoxicity on leaflets after PPO fumigation; Bars followed by the same letter are not significantly different as denoted by the Ismeans statement of the GLIMMIX procedure in SAS version 9.4 at the $5 \%$ level of significance.
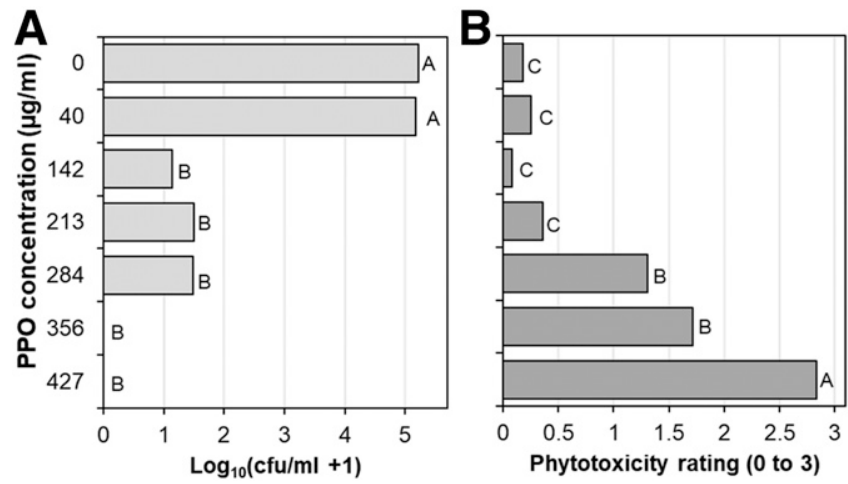

Fig. 4. Effect of propylene oxide (PPO) fumigation concentrations applied to diseased strawberry leaflets in a vacuum-fumigation chamber on Xanthomonas fragariae populations recovered from treated leaflets (A) and leaflet phytotoxicity (B). Bars followed by the same letter are not significantly different as denoted by the Ismeans statement of the GLIMMIX (A) or the MIXED (B) procedures in SAS version 9.4 at the $5 \%$ level of significance. 
each experiment, and calibration studies were conducted prior to fumigation. A vacuum was applied to the chamber. The appropriate volume of gaseous carbon dioxide was added to maintain an 11-fold excess relative to the targeted PPO dose (Jones 1933) that was then introduced as a liquid using a syringe. Following complete vaporization of the fumigant after approximately $3 \mathrm{~min}$, chamber valves were opened to reestablish atmospheric pressure. For each treatment, samples of chamber headspace were taken at regular intervals during the 2-h fumigation duration and analyzed for concentration of the gaseous fumigant using gas chromatography (Walse et al. 2013). After fumigation, lids were opened, and chambers were aerated. Control chambers were injected with water equivalent to the largest volume of PPO used. In each trial, a single chamber was used for each PPO rate (i.e., 40, 142, 213, 284, 356, or $427 \mu \mathrm{g} / \mathrm{ml}$ ). The experiment was done four times. PPO was evaluated at $40 \mu \mathrm{g} / \mathrm{ml}$ in trials 1 and 2 only and at $142 \mu \mathrm{g} / \mathrm{ml}$ in trials 3 and 4 only.

Rating of leaflet phytotoxicity and reisolation and enumeration of viable bacteria after fumigation. After fumigation, leaves were either processed immediately or stored at $2^{\circ} \mathrm{C}$ for up to $48 \mathrm{~h}$. Leaflets were visually rated for PPO phytotoxicity using a scale based on leaf surface darkening/purpling of nondiseased areas. The scale was as follows: $0=$ healthy, no visible darkening; $1=$ leaflet slightly darkened but still appearing healthy; $2=$ obvious darkening but leaflet still mostly green; and 3 = leaflet mostly purple and/or brown (necrosis) on the upper leaf surface (Fig. 5).

Bacterial isolations were done for each leaflet to enumerate viable bacterial populations present in tissues. For this, leaflets were surface sterilized for 1 min with $1 \%$ sodium hypochlorite and rinsed twice with sterile deionized water. From each leaflet, a 14-mm-diameter disc was removed from the area of highest disease severity, cut into pieces, and placed into a 1.7- $\mathrm{ml}$ microcentrifuge tube containing $500 \mu \mathrm{l}$ of sterile deionized water and a 5-mm-diameter stainlesssteel ball. Tubes were vortexed for $10 \mathrm{~min}$ to macerate tissues. Suspensions were diluted serially to a final dilution of 1:500 and plated radially in an exponential deposition onto 10-cm WBN medium plates using a spiral plater (Autoplate 4000; Spiral Biotech, Norwood, MA). X. fragariae colonies were enumerated after 5 to 6 days at $25^{\circ} \mathrm{C}$ using templates and enumeration tables (Spiral Biotech). Colonies were verified as $X$. fragariae using morphological and growth rate characteristics, and a subset of colonies was subjected to polymerase chain reaction (PCR) using species-specific primers 245A and 245B (Pooler et al. 1996).

Effect of postharvest PPO fumigation on sepal and fruit appearance and susceptibility of fruit to fungal decays. Two studies were conducted using fruit from an untreated strawberry field at UCR or organically grown fruit from a local market. Fruit were placed horizontally into plastic trays, and the upper sides were inoculated using an atomizer (DeVilbiss) with a spore suspension $\left(5 \times 10^{4}\right.$ spores/ $\mathrm{ml}$ ) of B. cinerea (isolate 1356) grown on King's medium B (King et al. 1954). Fruit were incubated at $25^{\circ} \mathrm{C}$ and $>95 \% \mathrm{RH}$ for $2 \mathrm{~h}$ and then air dried for $2 \mathrm{~h}$. Spore germination was confirmed at the time of fumigation by microscopic observation of a potato dextrose agar plate that was inoculated with the same spore suspension. Fruit were loaded into jars with nine to 12 fruit per jar, the fumigant was applied, and jars were vented as described above for UCR-conducted leaflet fumigation trials. Fruit were stored at $2{ }^{\circ} \mathrm{C}$ for 3 days. Fruit were visually rated for PPO phytotoxicity using a scale based on darkening/purpling of veins of fruit sepals. The scale was as follows: $0=$ healthy, no visible damage; $1=$ $<50 \%$ of the calyx with purple veining, still appearing healthy; $2=\geq 50 \%$ of the calyx with purple veining; $3=$ purple veining and necrosis on $<50 \%$ of the calyx; and $4=\geq 50 \%$ of the calyx brown and necrotic. Fruit receptacles were also rated for any discoloration or necrosis using a plus/minus rating. Fruit were then placed into plastic trays and incubated for 5 days at $15^{\circ} \mathrm{C},>95 \%$ $\mathrm{RH}$. The incidence of gray mold and naturally developing Rhizopus rot was assessed based on the number of diseased berries with characteristic mycelial growth of the total number of berries in each jar replication. Fungal isolations were done on subsamples of infected fruit to confirm the pathogens.
Statistical analysis of data. All statistical analyses were performed using SAS (version 9.4, SAS Institute, Cary, NC) with a significance value of $\alpha=0.05$. For greenhouse efficacy trials, leaf incidence data were subjected to arcsine square-root transformation prior to analysis. The effects of treatment on disease incidence, relative disease incidence, and relative lesion number per leaf were determined using generalized linear mixed models with the GLIMMIX procedure. For this, treatment was treated as a fixed effect, and trial, replication (block), and the overall error term were treated as random effects. Fixed effects were tested for significance, and least squares treatment means were constructed using the lsmeans statement with the Tukey adjustment in PROC GLIMMIX. Contrast estimates for pairs of treatments were used to determine multiple comparison differences among treatment means.

For methyl bromide fumigation trials, a linear mixed model (PROC MIXED) was used for analysis of bacterial population data. For trial 1, treatment and temperature were treated as fixed effects, and replicate leaflet and the overall error term were treated as random effects. For trial 2, treatment was treated as a fixed effect, and replicate leaflet, spatial location, and the overall error term were treated as random effects. Fixed factors were tested for significance.

For leaflet fumigation trials with PPO in static or active chambers, phytotoxicity ratings were ranked (PROC RANK) prior to analysis. The effects of treatment on bacterial population size (treatment efficacy) or phytotoxicity were determined using generalized linear mixed model (PROC GLIMMIX) or linear mixed model (PROC MIXED) analyses, respectively. For these, treatment, temperature, and the interaction treatment $\times$ temperature (static-chamber trials 2 and 3) were treated as fixed effects, and trial, replicate, and the overall error term were treated as random effects. Fixed effects were tested for significance. For static-chamber trials, bacterial population data were averaged by replicate jar, and linear regression analysis (PROC REG) was performed following transformation using $y=$ $\log _{10}($ count $/ \mathrm{ml}+1)$. For active-chamber trials, multiple comparison differences among treatment means were obtained using the lsmeans statement in PROC GLIMMIX or PROC MIXED, as described above.

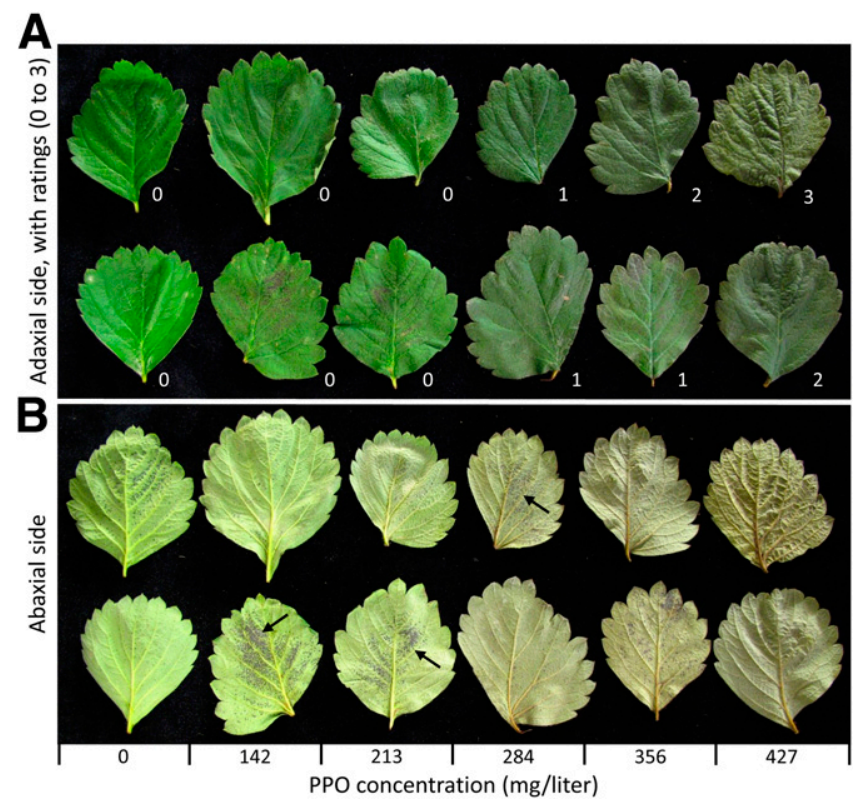

Fig. 5. Examples of phytotoxicity of adaxial (A) or abaxial (B) sides of leaflets that were treated with propylene oxide in a vacuum-infiltration chamber. Leaflets were rated for phytotoxicity on nondiseased tissues of the adaxial sides using a scale from 0 to 3 . The rating as indicated in $A$ at the lower right-hand corner of each leaflet ranged as follows: $0=$ healthy, no visible darkening; 1 = leaflet slightly darkened but still appearing healthy; 2 = obvious darkening but leaflet still mostly green; and $3=$ leaflet very dark with purple and/or brown tones. Examples of severe disease symptoms are indicated by arrows on the abaxial side. 
For fruit fumigation studies, fungal disease incidence data were arcsine square-root transformed, whereas phytotoxicity ratings were ranked (PROC RANK). These data were subjected to GLIMMIX or MIXED model analyses, respectively, as described for the staticchamber PPO fumigation above.

\section{Results}

$X$. fragariae strain sensitivity to copper and infection of strawberry leaves. Strain 1298 was found to be copper sensitive with growth similar to the control at $10 \mu \mathrm{g} / \mathrm{ml}$ of MCE, reduced growth at $20 \mu \mathrm{g} / \mathrm{ml}$ of MCE, and no visible growth at $30 \mu \mathrm{g} / \mathrm{ml}$ of MCE. In producing infected leaves for fumigation tests, angular, water-soaked lesions ( 0.5 to $2.5 \mathrm{~mm}$ in diameter) characteristic of ALS were present approximately 10 to 14 days after inoculation in the greenhouse. $X$. fragariae infection was confirmed by reisolation, in which colonies with typical morphology on WBN medium were visualized as described previously (EPPO 2006). Colonies were initially off-white, becoming light yellow, convex, shiny, and mucoid after 4 to 6 days at $25^{\circ} \mathrm{C}$. PCR amplification with $X$. fragariaespecific primers $245 \mathrm{~A}$ and $245 \mathrm{~B}$ resulted in a single band of the expected 300-bp length.

Efficacy of bactericide applications to manage ALS in greenhouse studies. Bactericide treatment effects were significant $(P<0.0001)$ for disease incidence in experiment 1 (Fig. 1). Kasugamycin, copper, and copper/kasugamycin mixture treatments were not statistically $(P>0.05)$ different from each other and had similar disease incidences (average 60.2, 46.7, and $46.9 \%$, respectively) as the control (average 56.3\%). All treatments containing ATD, however, significantly $(P<0.05)$ reduced disease incidence from that of the control. ATD at $500 \mu \mathrm{g} / \mathrm{ml}$ by itself or in mixture with copper resulted in the lowest numerical incidence, both with an average of $4.1 \%$. These treatments were statistically similar to the kasugamycin/ATD (average 10.1\%) and copper/250 $\mu \mathrm{g} / \mathrm{ml}$ ATD (average $11.9 \%$ ) mixture treatments. When the ATD rate was reduced to $50 \mu \mathrm{g} / \mathrm{ml}$ in a mixture with copper, disease incidence numerically increased (average $22.9 \%$ ) as compared with higher rates (Fig. 1).

In the second experiment, mean disease incidence in the control was $45.3 \%$ with a mean of 75.3 lesions/leaf, and treatment had a significant $(P<0.0001)$ effect on disease incidence, relative disease incidence $(P=0.0221$; Fig. $2 \mathrm{~A})$, and relative number of lesions $(P=0.0233$; Fig. 2B). The mixture of copper with ZTD resulted in the lowest relative disease incidence (average $8.8 \%$ ) and was significantly $(P<0.05)$ more effective than copper alone (Fig. 2A). Similarly, this treatment had the lowest relative lesion number (average 0.13 ) and was significantly different from ZTD at $250 \mu \mathrm{g} / \mathrm{ml}$ (Fig. 2B).

Effect of methyl bromide fumigation of plant material with ALS symptoms on survival of $X$. fragariae. There was no statistical difference ( $P=0.1858$ and $P=0.7500$ for trials 1 and 2 , respectively) between $X$. fragariae populations recovered from control (average $1.7 \times 10^{5} \mathrm{CFU} / \mathrm{ml}$ in trial 1 and $2.2 \times 10^{5} \mathrm{CFU} / \mathrm{ml}$ for trial 2) and methyl bromide-treated (average $2.2 \times 10^{5} \mathrm{CFU} / \mathrm{ml}$ in trial 1 and $1.9 \times 10^{5} \mathrm{CFU} / \mathrm{ml}$ for trial 2) leaflets. No phytotoxicity was observed for the methyl bromide treatments at commercial rates (data not shown), but some dehydration of leaf tissues occurred in the commercially conducted experiment.

Effect of PPO fumigation of plant material with ALS symptoms on survival of $X$. fragariae. In trials using static chambers with passive fumigant infiltration, the effect of PPO fumigation on bacterial survival was significant $(P<0.0001)$, whereas the effects of temperature and the interaction treatment $\times$ temperature were not significant ( $P=0.7426$ and $P=0.7674$, respectively). The regression of PPO concentration on viable bacterial population size was significant $(P<0.0001)$ and had an $R$-square value of 0.8639 (Fig. 3A). Increasing PPO concentrations resulted in a reduction of bacterial populations.

In trials using active chambers with vacuum fumigant infiltration, PPO was found to significantly $(P<0.0001)$ affect bacterial population size. Bacterial populations averaged $5.3 \log _{10}(\mathrm{CFU} / \mathrm{ml}+1)$ in untreated control leaflets (Fig. 4A). Among PPO concentrations evaluated, rates from 142 to $427 \mu \mathrm{g} / \mathrm{ml}$ resulted in a significant, 2.8- to $>5-\log$ reduction in viable bacteria (i.e., 211 to $0 \mathrm{CFU} / \mathrm{ml}$, respectively) compared with the control (Fig. 4A). X. fragariae was not recovered from leaflets exposed to 356 or $427 \mu \mathrm{g} / \mathrm{ml}$ of PPO, as well as some replications of leaflets treated with 142,213 , or $284 \mu \mathrm{g} / \mathrm{ml}$ of PPO.

Effect of PPO fumigation on leaflet appearance (phytotoxicity). In static-chamber infiltration trials, PPO was found to significantly $(P<0.0001)$ contribute to phytotoxicity. Temperature and the interaction treatment $\times$ temperature did not significantly affect phytotoxicity ( $P=0.1549$ and $P=0.1336$, respectively) in trials 2 and 3 , in which temperature was evaluated. Multiple comparisons between treatment means indicated that PPO at $427 \mu \mathrm{g} / \mathrm{ml}$ resulted in significantly $(P<0.05)$ higher phytotoxicity (average rating 0.44$)$ compared with the untreated control (average rating 0.06), the 40$\mu \mathrm{g} / \mathrm{ml}$ rate of PPO (average rating 0.0 ), and the $213-\mu \mathrm{g} / \mathrm{ml}$ rate of PPO (average rating 0.09; Fig. 3B). Visually, phytotoxicity was sometimes present as a slight darkening of the still-green leaves at the highest PPO rate evaluated.

PPO also significantly $(P<0.0001)$ affected phytotoxicity in the vacuum-infiltration trials (Fig. 4B). Control leaflets had a healthy green appearance (average rating of 0.18 ) and were statistically similar $(P>0.05)$ to leaflets exposed to PPO at 40,142 , or $213 \mu \mathrm{g} / \mathrm{ml}$, which had average phytotoxicity ratings of $\leq 0.36$ (Figs. 4B and 5). Average ratings for leaflets treated with 284, 356 , or $427 \mu \mathrm{g} / \mathrm{ml}$ of PPO were significantly higher, and phytotoxicity numerically increased with increasing rates. Phytotoxicity ratings for PPO at $284 \mu \mathrm{g} / \mathrm{ml}$ (average rating 1.31) and $356 \mu \mathrm{g} / \mathrm{ml}$ (average rating 1.72) were statistically similar and evident as darkened leaf tissue. These ratings were significantly $(P<$ 0.05 ) lower than ratings for PPO at $427 \mu \mathrm{g} / \mathrm{ml}$ (average rating 2.84), for which nearly all leaflets were very dark and purplish in color (Figs. 4B and 5).

Effect of postharvest PPO fumigation on sepal and fruit appearance and fruit susceptibility to fungal decays. Phytotoxicity ratings of fruit sepals were not significantly different among treatments $(P=0.4368)$ or temperatures $(P=0.5198)$. Average ratings of the control and the fumigations at 213 and $427 \mu \mathrm{g} / \mathrm{ml}$ of PPO were $1.77,1.70$, and 1.63 for all temperatures, respectively. No phytotoxicity was observed on fruit in any of the trials.

There was no statistical difference in decay incidence due to fumigation treatment $(P=0.4222$ for $B$. cinerea and $P=0.7418$ for $R$. stolonifer $)$ or temperature $(P=0.3639$ for $B$. cinerea and $P=0.7284$ for $R$. stolonifer). Average fruit disease incidence was 66.0 and $44.5 \%$ for the control, 72.7 and $41.5 \%$ for fruit treated with $213 \mu \mathrm{g} / \mathrm{ml}$ of PPO, and 70.7 and $46.5 \%$ for fruit treated with $427 \mu \mathrm{g} / \mathrm{ml}$ of PPO for gray mold and Rhizopus rot, respectively.

\section{Discussion}

In this study, we identified promising new treatments for the preharvest management of angular leaf spot and for the postharvest fumigation of infected strawberry tissues to eradicate viable cells of the pathogen $X$. fragariae. Following further evaluation and registration, these management tools could be combined in a systems approach (FAO 2011; Jang and Moffitt 1994) for ALS management with the end goal of a reduced risk in exporting the quarantine bacterium $X$. fragariae from California and other strawberry-growing regions where the pathogen is present.

Bacterial diseases can increase rapidly under favorable environments, and field treatments are needed in an integrated disease management program to protect plants from infection and delay the onset of an epidemic. Thus, preharvest bactericide treatments were evaluated in this study. Copper formulations are among the few registered products for use against ALS in the United States. These, however, are only moderately efficacious (Merteley 2010; Roberts et al. 1997). In one experiment of our study in which a rate of $175 \mu \mathrm{g} / \mathrm{ml}$ of MCE was used, disease incidence was not significantly reduced compared with the control even though in vitro, $X$. fragariae strain $X f 1298$ was sensitive to copper with no growth at $30 \mu \mathrm{g} / \mathrm{ml}$ of 
MCE. In contrast to previous reports (Merteley 2010; Roberts et al. 1997), no copper phytotoxicity was observed in our studies, likely because only one application was made to plants and the lowest labeled rate was used. The antibiotic kasugamycin, when applied alone at $100 \mu \mathrm{g} / \mathrm{ml}$ or in mixtures with copper, was also not effective in reducing ALS. In contrast, in studies on bacterial spot of tomato (caused by $X$. perforans and other species), kasugamycin was effective (Vallad et al. 2010). For walnut blight caused by $X$. arboricola pv. juglandis, efficacy of kasugamycin/copper mixtures was higher than for kasugamycin by itself and was similar to the industry standard copper/mancozeb (Nguyen et al. 2016).

Treatments containing ATD or ZTD consistently were highly effective in reducing ALS. ATD or ZTD when applied alone at $500 \mu \mathrm{g} / \mathrm{ml}$ significantly reduced the disease, and no additional benefits in performance were observed when ATD was used in mixtures with kasugamycin or copper, whereas ZTD mixed with copper showed improved performance over copper or the low rate of ZTD alone. These compounds therefore have excellent potential as new treatments for managing ALS. Additionally, ZTD has demonstrated activity against Xanthomonas spp., including $X$. oryzae pv. oryzae, causal agent of bacterial leaf blight of rice (Chen et al. 2014; Zhang et al. 2013), and a commercial formulation is registered for agricultural use in China. Our evaluation of the ZTD product may support registration in the United States if a registrant is identified. The specific mode of action is not known for ATD (5-amino-1,3,4-thiadiazole2-thiol) or ZTD (Chen et al. 2014; Zhang et al. 2013). However, a compound with a similar heterocyclic ring, 1,2,4-thiadiazole, is proposed to interfere with cell peroxidation and inhibit lipid synthesis or transport in the cell membrane (Hu et al. 2014), whereas other thiadiazole derivatives are believed to be involved in host plant defense induction (FRAC 2018). Evaluation of ATD, ZTD, or similar products should be pursued in the field, and registration should be pursued both for nursery use to reduce the initial introduction of $X$. fragariae into fruit production fields and for fruit production to reduce the disease on harvested fruit that may be exported. Additional greenhouse and field evaluations of thiadiazole derivatives against $X$. fragariae and other bacterial plant pathogens may provide new nonantibiotic, non-copper-based treatments for managing bacterial diseases including ALS.

Methyl bromide had no effect in reducing viable $X$. fragariae populations in infected leaf material when tested at commercial fumigation rates. This reflects industry experience in which commercial quarantine treatments with methyl bromide for insect pests in strawberries destined for export to restrictive markets (USDA-APHIS 2016; Walse et al. 2012) still result in ALS detections (AQIS 2011). In our studies, we identified PPO as a potential new commercial fumigant for strawberries that can dramatically reduce viable populations of $X$. fragariae in diseased plant tissues while causing little to no phytotoxicity at effective rates. Diseased leaves were used because they could be consistently produced in large enough amounts for replicated experiments. The primary export concern for the fresh-market California strawberry industry, however, are infected fruit calyces. Calyxes, likely due to their smaller size, had a low disease incidence following our inoculations. Leaves are acceptable surrogates because they are anatomically similar to calyxes. Additionally, in our reisolations of $X$. fragariae from symptomatic calyx tissues, bacterial and fungal contaminants often inhibited growth of $X$. fragariae in vitro, as observed and described by Henry et al. (2016), resulting in additional complications in obtaining reliable data.

Temperatures and fumigation duration in our studies were selected based on current commercial fumigation practices for insect control in the export strawberry fruit industry. PPO was tested using staticand vacuum-infiltration systems with slightly different results for efficacy and phytotoxicity at corresponding rates, temperatures, and durations. In general, static infiltration of PPO at lower rates (e.g., $213 \mu \mathrm{g} / \mathrm{ml}$ ) resulted in lower efficacy in reducing viable bacterial populations and lower phytotoxicity to leaflets compared with vacuum infiltration, whereas higher rates in the static system provided similar 3- to $5-\log$ reductions in viable bacteria with less phytotoxicity. Vacuum infiltration replaces air inside the chamber and leaf mesophyll with PPO, resulting in increased exposure of the bacterial pathogen and inner leaf tissues to PPO. Commercially, both static and vacuum systems are used for postharvest fumigation of different commodities (USDA-APHIS 2016), although for strawberries, methyl bromide is usually applied using a static system with fans to aid in the dispersal of the fumigant. At the same temperatures and treatment duration, the PPO rates to reduce viable $X$. fragariae were higher than rates that provide control of mites and insects of quarantine concern that infest strawberry and other fruits (S. Walse, unpublished). This work provides evidence to support continued efforts to register PPO as a fumigant for multiple pests as well as ALS of strawberry.

Fruit phytotoxicity and fungal decay studies approximated the temperature regime and timelines of fumigation treatments for exported fruit, with 1 to 3 days of cold storage $\left(2^{\circ} \mathrm{C}\right)$ after treatment during transportation and moderate temperatures during the market and consumer shelf life. No significant phytotoxicity to fruit and calyxes was observed, and only minor phytotoxicity was observed on leaves in static-infiltration systems. PPO fumigation did not significantly reduce decay or change fruit susceptibility to the major postharvest decays evaluated. Effective postharvest fumigation control of $B$. cinerea and $R$. stolonifer was demonstrated in strawberry using acetaldehyde, but this has not been commercialized (Prasad and Stadelbacher 1974).

To our knowledge, this is the first demonstration that fumigation of a fresh-market commodity can result in a reduction of several $\log$ scales in populations of a plant pathogenic bacterium. This may potentially be used in response to a quarantine detection. Most fumigation research has focused on reducing quarantine insect pests (Follett and Neven 2006; Heather and Hallman 2007; USDA-APHIS 2016), whereas other studies involved pathogens causing foodborne illnesses (Danyluk et al. 2005; Kasler and Yousef 2017), postharvest fungal decays (Gabler et al. 2010; Sholberg 1998), or the improvement of postharvest shelf life and fruit quality (Mahajan et al. 2014; Wills et al. 2000). Plant diseases of quarantine concern are more commonly mitigated by chemical, physical (e.g., hot water or steam), or irradiation treatments, or a combination of these (Eckert and Ogawa 1988; Mahajan et al. 2014; USDA-APHIS 2016). Aqueous postharvest treatments cannot be used because wetting of strawberry fruit reduces quality and shortens shelf life (Eckert and Ogawa 1988).

Additional studies on the evaluation of PPO fumigation on a range of strawberry cultivars from different growing seasons and regions are warranted. Other factors that will need to be considered include effects of increased fruit load on efficacy, PPO sorption into the organic load, and chemical residues (Jimenez et al. 2015; Walse et al. 2013, 2016). PPO is registered for nut crops with residue limits in almond of $300 \mathrm{mg} / \mathrm{kg}$ in the United States (U.S. EPA 2012) and $100 \mathrm{mg} / \mathrm{kg}$ in Australia (APVMA 2018). PPO readily volatilizes at ambient temperatures, breaks down relatively quickly into propylene glycol and water, and is not known to persist in the environment or pose major environmental risks (U.S. EPA 2006). Furthermore, because infected transplants are the primary mechanism of introduction of $X$. fragariae into production fields, fumigation of transplants with PPO could also be evaluated.

In international trade, a science-based decision-making process is the foundation for quarantine regulations. For insects, required pest reductions are based on "probit 9," in which $99.9968 \%$ mortality ( 3 survivors per 100,000 treated) is achieved (Follett and Neven 2006), whereas in food safety, an approximately 3- to 5-log reduction in bacterial populations in a food product is considered "pasteurized" (Breidt et al. 2013; U.S. FDA 2001). In the present study, a 50- $\mu 1$ aliquot of diseased leaf tissue extract was plated onto selective medium resulting in a detection threshold of $1 \mathrm{CFU} / 50 \mu \mathrm{l}$ or $20 \mathrm{CFU} / \mathrm{ml}$ following a 1:500 dilution of the original leaf macerate. This corresponds to approximately $3.3 \times 10^{6} \mathrm{CFU} / \mathrm{cm}^{2}$ of diseased leaf tissue used in our study. Plating of additional replicates, larger volumes, or using lower dilutions would increase the sensitivity of detection. PPO fumigation resulted in a multiple-log, sometimes 5-log, 
reduction of viable $X$. fragariae populations compared with controls and, thus, is similar to reductions targeted in food safety.

Currently, PCR techniques are the standard for $X$. fragariae detection in quarantine inspection, but these cannot differentiate between live and dead microbial cells. Confirmatory bacterial isolation that enables a better estimate of the live population is too slow for a perishable fruit such as strawberries and for quarantine purposes because $X$. fragariae takes 4 to 7 days to develop medium-sized colonies (EPPO 2006; Henry et al. 2016). DNA-intercalating dyes can reduce PCR signals from dead cells (Fittipaldi et al. 2012). These are currently being evaluated for $X$. fragariae detection in strawberry tissues (Wang and Turechek 2015) and are used for live detection or evaluation of pasteurization/sterilization efficacies for other regulated bacterial plant (Temple et al. 2013) and foodborne (Fang et al. 2018) pathogens. If ALS was detected during quarantine inspections, standardized PPO fumigation protocols to obtain a multiple-log reduction in the pathogen population and confirmatory PCR detection methods for living bacteria could be part of an international trade agreement.

\section{Acknowledgments}

We thank J. Leveau and W. D. Gubler for providing the bacterial isolate used in these studies. We thank M. Nelson and Plant Sciences Inc. for assistance with the commercial methyl bromide fumigation and for donating strawberry transplants. We thank L. Jimenez for assisting in fumigations at USDA, Parlier, CA, and D. Cary for coordinating these studies. We thank H. Förster for critically reviewing this manuscript and D. Murillo and G. Gemelga for assisting in greenhouse trials, bacterial isolations, and data collection. This research is part of a Ph.D. dissertation undertaken by S. E. Haack.

\section{Literature Cited}

Australian Government Department of Agriculture and Water Resources (AGDA). 2018. Case details-Import conditions. Fresh berries for human consumption. Strawberries-Grown in the United States, grown and exported from California only. Australian Biosecurity Import Conditions. Database. https://bicon. agriculture.gov.au/BiconWeb4.0/.

Australian Pesticides and Veterinary Medicines Authority (APVMA). 2018. Australia New Zealand Food Standards Code-Schedule 20-Maximum residue limits. F2018C00171. https://www.legislation.gov.au/Details/ F2018C00171.

Australian Plant Quarantine and Inspection Service (AQIS). 2011. Work Plan for the Preclearance of California Strawberries. Department of Agriculture, Fisheries and Forestry, Canberra, Australia.

Bestfleisch, M., Richter, K., Wensing, A., Wünsche, J. N., Hanke, M. V., Höfer, M., Schulte, E., and Flachowsky, H. 2015. Resistance and systemic dispersal of Xanthomonas fragariae in strawberry germplasm (Fragaria L.). Plant Pathol. 64:71-80.

Breidt, F., Kay, K., Cook, J., Osborne, J., Ingham, B., and Arritt, F. 2013. Determination of 5-log reduction times for Escherichia coli 0157:H7, Salmonella enterica, or Listeria monocytogenes in acidified foods with $\mathrm{pH}$ 3.5 or 3.8. J. Food Prot. 76:1245-1249.

Chen, Y., Yang, X., Gu, C.-Y., Zhang, A.-F., Zhang, Y., Wang, W.-X., Gao, T.-C., Yao, J., and Yuan, S.-K. 2014. Activity of a novel bactericide, zinc thiazole against Xanthomonas oryzae pv. oryzae in Anhui Province of China. Ann. Appl. Biol. 166:129-135.

Danyluk, M. D., Uesugi, A. R., and Harris, L. J. 2005. Survival of Salmonella enteritidis PT 30 on inoculated almonds after commercial fumigation with propylene oxide. J. Food Prot. 68:1613-1622.

Daugovish, O., Su, H., and Gubler, W. D. 2009. Preplant fungicide dips of strawberry transplants to control anthracnose caused by Colletotrichum acutatum in California. HortTechnology 19:317-323.

Eckert, J. W., and Ogawa, J. M. 1988. The chemical control of postharvest diseases: Deciduous fruits, berries, vegetables and root/tuber crops. Annu. Rev. Phytopathol. 26:433-469.

European and Mediterranean Plant Protection Organization (EPPO). 1997. Data sheet on Xanthomonas fragariae. Pages 1124-1128 in: Quarantine Pests for Europe, 2nd Ed. I. M. Smith, D. G. McNamara, P. R. Scott, and M. Holderness, eds. CABI, Wallingford, U.K.

European and Mediterranean Plant Protection Organization (EPPO). 2006. Diagnostic protocol for Xanthomonas fragariae. PM 7/65. OEPP/EPPO Bull. 36:135-144.

Fang, J., Wu, Y., Qu, D., Ma, B., Yu, X., Zhang, M., and Han, J. 2018. Propidium monoazide real time loop-mediated isothermal amplification for specific visualization of viable Salmonella in food. Lett. Appl. Microbiol. 67:79-88.

Federal Register. 2003. Protection of Stratospheric Ozone: Process for Exempting Quarantine and Preshipment Applications of Methyl Bromide. Federal Register 68(1):237-254. https://www.govinfo.gov/content/pkg/FR-2003-0102/html/02-32986.htm
Fittipaldi, M., Nocker, A., and Codony, F. 2012. Progress in understanding preferential detection of live cells using viability dyes in combination with DNA amplification. J. Microbiol. Methods 91:276-289.

Follett, P. A., and Neven, L. G. 2006. Current trends in quarantine entomology Annu. Rev. Entomol. 51:359-385.

Food and Agriculture Organization of the United Nations (FAO). 2011 International Standards for Phytosanitary Measures (ISPM), No. 14, 2002. The use of integrated measures in a systems approach for pest risk management. http://www.fao.org/3/a-y4221e.pdf

Frija, L. M. T., Pombeiro, A. J. L., and Kopylovich, M. N. 2016. Coordination chemistry of thiazoles, isothiazoles and thiadiazoles. Coord. Chem. Rev. 308: $32-55$

Fungicide Resistance Action Committee (FRAC). 2018. FRAC Code List 2018: Fungicides sorted by mode of action (including FRAC code numbering). http://www.frac.info.

Gabler, F. M., Smilanick, J. L., Mansour, M. F., and Karaca, H. 2010. Influence of fumigation with high concentrations of ozone gas on postharvest gray mold and fungicide residues on table grapes. Postharvest Biol. Technol. 55:85-90.

Gubler, W. D., Feliciano, A. J., Bordas, A. C., Civerolo, E. C., Melvin, J. A., and Welch, N. C. 1999. First report of blossom blight of strawberry caused by Xanthomonas fragariae and Cladosporium cladosporioides in California. Plant Dis. 83:400.

Gubler, W. D., Gordon, T. R., Koike, S. T., and Browne, G. T., eds. 2005. Strawberry Angular Leaf Spot. UC IPM, Statewide Integrated Pest Management Program. https://www2.ipm.ucanr.edu/agriculture/strawberry/ angular-leaf-spot/.

Heather, N. W., and Hallman, G. J. 2007. Disinfestation by fumigation. Pages 153-170 in: Pest Management and Phytosanitary Trade Barriers. CAB International, Wallingford, U.K.

Henry, P. M., Gebben, S. J., Tech, J. J., Yip, J. L., and Leveau, J. H. J. 2016. Inhibition of Xanthomonas fragariae, causative agent of angular leaf spot of strawberry, through iron deprivation. Front. Microbiol. 7:1589.

Hildebrand, D. C., Schroth, M. N., and Wilhelm, S. 1967. Systemic invasion of strawberry by Xanthomonas fragariae causing vascular collapse. Phytopathology 57:1260-1261.

Hildebrand, P. D., Braun, P. G., Renderos, W. E., Jamieson, A. R., McRae, K. B., and Binns, M. R. 2005. A quantitative method for inoculating strawberry leaves with Xanthomonas fragariae, factors affecting infection, and cultivar reactions. Can. J. Plant Pathol. 27:16-24.

Hu, Y., Li, C.-Y., Wang, X.-M., Yang, Y.-H., and Zhu, H.-L. 2014. 1,3,4 Thiadiazole: Synthesis, reactions, and applications in medicinal, agricultural, and materials chemistry. Chem. Rev. 114:5572-5610.

Jang, E. B., and Moffitt, H. R. 1994. Systems approaches to achieving quarantine security. Pages 225-239 in: Quarantine Treatment for Pests of Food Plants. J. L. Sharp and G. J. Hallman, eds. Westview Press, Boulder, CO.

Jimenez, L. R., Hall, W. A., IV, Rodriquez, M. S., Cooper, W. J., Muhareb, J., Jones, T., and Walse, S. S. 2015. Quantifying residues from postharvest propylene oxide fumigation of almonds and walnuts. J. AOAC Int. 98:1423-1427.

Jones, R. M. 1933. Reducing inflammability of fumigants with carbon dioxide. Ind. Eng. Chem. 25:394-396.

Kasler, D., and Yousef, A. E. 2017. Antimicrobial gases for food application Pages 327-348 in: Microbial Control and Food Preservation, Food Microbiology and Food Safety. V. Juneja, H. Dwivedi, and J. Sofos, eds. Springer, New York, NY.

Kennedy, B. W., and King, T. H. 1962a. Angular leaf spot of strawberry caused by Xanthomonas fragariae sp. nov. Phytopathology 52:873-875.

Kennedy, B. W., and King, T. H. 1962b. Studies on epidemiology of bacterial angular leaf spot on strawberry. Plant Dis. Rep. 46:360-363.

King, E. O., Ward, M. K., and Raney, D. E. 1954. Two simple media for the demonstration of pyocyanin and fluorescin. J. Lab. Clin. Med. 44:301-307.

Koike, H. 1965. The aluminum-cap method for testing sugarcane varieties against leaf scald disease. Phytopathology 55:317-319.

Maas, J. L. 1998. Angular leaf spot. Pages 16-17 in: Compendium of Strawberry Diseases, 2nd Ed. J. L. Maas, ed. American Phytopathological Society, St. Paul, MN.

Mahajan, P. V., Caleb, O. J., Singh, Z., Watkins, C. B., and Geyer, M. 2014 Postharvest treatments of fresh produce. Philos. Trans. R. Soc. A 372. doi: 10.1098/rsta.2013.0309.

Mahuku, G. S., and Goodwin, P. H. 1997. Presence of Xanthomonas fragariae in symptomless strawberry crowns in Ontario detected using a nested polymerase chain reaction (PCR). Can. J. Plant Pathol. 19:366-370.

Merteley, J. C. 2010. Efficacy of acibenzolar-S-methyl and copper fungicides for the control of angular leaf spot of strawberry. (Abstr.) Phytopathology 100:S83.

Milholland, R. D., Ritchie, D. F., Daykin, M. E., and Gutierrez, W. A. 1996 Multiplication and translocation of Xanthomonas fragariae in strawberry. Adv. Strawb. Res. 15:13-17.

Nguyen, K., Förster, H., Wade, L., and Adaskaveg, J. 2016. Kasugamycin mixtures with copper, mancozeb, or a thiadiazole improve bactericidal inhibition and efficacy of treatments against walnut blight. (Abstr.) Phytopathology 106:S4.62.

Pooler, M. R., Ritchie, D. F., and Hartung, J. S. 1996. Genetic relationships among strains of Xanthomonas fragariae based on random amplified polymorphic DNA PCR, repetitive extragenic palindromic PCR, and enterobacterial 
repetitive intergenic consensus PCR data and generation of multiplexed PCR primers useful for the identification of this phytopathogen. Appl. Environ. Microbiol. 62:3121-3127.

Prasad, K., and Stadelbacher, G. J. 1974. Effect of acetaldehyde vapor on postharvest decay and market quality of fresh strawberries. Phytopathology 64:948-951.

Roberts, P. D., Berger, R. E., Jones, J. B., Chandler, C. K., and Stall, R. E. 1997. Disease progress, yield loss, and control of Xanthomonas fragariae on strawberry plants. Plant Dis. 81:917-921.

Roberts, P. D., Jones, J. B., Chandler, C. K., Stall, R. E., and Berger, R. D. 1996. Survival of Xanthomonas fragariae on strawberry in summer nurseries in Florida detected by specific primers and nested polymerase chain reaction. Plant Dis. 80:1283-1288.

Sholberg, P. L. 1998. Fumigation of fruit with short-chain organic acids to reduce the potential of postharvest decay. Plant Dis. 82:689-693.

Sweeney, L. M., Kirman, C. R., Albertini, R. J., Tan, Y.-M., Clewell, H. J., Filser, J. G., Csanády, G., Pottenger, L. H., Banton, M. I., Graham, C. J., Andrews, L. S., Papciak, R. J., and Gargas, M. L. 2009. Derivation of inhalation toxicity reference values for propylene oxide using mode of action analysis: Example of a threshold carcinogen. Crit. Rev. Toxicol. 39:462-486.

Temple, T. N., du Toit, L. J., Derie, M. L., and Johnson, K. B. 2013. Quantitative molecular detection of Xanthomonas hortorum pv. carotae in carrot seed before and after hot-water treatment. Plant Dis. 97:1585-1592.

Turechek, W. W., and Peres, N. A. 2009. Heat treatment effects on strawberry plant survival and angular leaf spot, caused by Xanthomonas fragariae, in nursery production. Plant Dis. 93:299-308.

U.S. Department of Agriculture (USDA). 2010. Fumigation and Chemistry Group of the Commodity Protection and Quality Research Unit. Agricultural Research Service, SJVASC, Parlier, CA 93648. http://www.ars.usda.gov//Main/site_ main.htm?docid $=18577$.

U.S. Department of Agriculture, Animal and Plant Health Inspection Service (USDA-APHIS). 2016. Treatment Manual. Plant Protection and Quarantine. https://www.aphis.usda.gov/import_export/plants/manuals/ports/downloads/ treatment.pdf.

U.S. Environmental Protection Agency (U.S. EPA). 2012. Tolerance actions: Propylene oxide, Environmental Protection Agency. EPA-HQOPP-20050253-0084. https://www.regulations.gov/document?D=EPA-HQ-OPP-20050253-0084.
U.S. Environmental Protection Agency (U.S. EPA). 2006. Reregistration eligibility decision for propylene oxide. Office of Prevention, Pesticides, and Toxic Substances. Case number 2560. 738-R-06-029. https://nepis.epa.gov/ Exe/ZyPDF.cgi/P1007LBZ.PDF?Dockey=P1007LBZ.PDF.

U.S. Food and Drug Administration (U.S. FDA). 2001. Analysis and evaluation of preventative control measures for the control and reduction/elimination of microbial hazards on fresh and fresh-cut produce. Center for Food Safety and Applied Nutrition. IFT contract no. 223-98-2333. https://wayback.archive-it. org/7993/20170111012926/http://www.fda.gov/Food/FoodScienceResearch/ SafePracticesforFoodProcesses/ucm090977.htm.

Vallad, G. E., Pernezny, K. L., Balogh, B., Wen, A., Figueiredo, J. F. L., Jones, J. B., Momol, T., Muchoveg, R. M., Havranek, N., Abdallah, N., Olson, S., and Roberts, P. D. 2010. Comparison of kasugamycin to traditional bactericides for the management of bacterial spot on tomato. Hortic. Sci. (Prague) 45:1834-1840

Walse, S. S., Jimenez, L. R., Hall, W. A., Tebbets, J. S., and Obenland, D. M. 2016 Optimizing postharvest methyl bromide treatments to control spotted wing drosophila, Drosophila suzukii, in sweet cherries from western USA. J. Asia Pac. Entomol. 19:223-232.

Walse, S. S., Krugner, R., and Tebbets, J. S. 2012. Postharvest treatment of strawberries with methyl bromide to control spotted wing drosophila, Drosophila suzukii. J. Asia Pac. Entomol. 15:451-456.

Walse, S. S., Myers, S. W., Yong-Biao, L., Bellamy, D. E., Obenland, D. Simmons, G. S., and Tebbets, S. 2013. Postharvest treatment of fresh fruit from California with methyl bromide for control of light brown apple moth (Lepidoptera: Tortricidae). J. Econ. Entomol. 106:1155-1163.

Wang, H., McTavish, C., and Turechek, W. W. 2018. Colonization and movemen of Xanthomonas fragariae in strawberry tissues. Phytopathology 108:681-690.

Wang, H., and Turechek, W. W. 2015. Detection of viable Xanthomonas fragariae cells in strawberry using propidium monoazide and long-amplicon quantitative PCR. (Abstr.) Phytopathology 105:S4.145.

Wills, R. B. H., Ku, V. V. V., and Leshem, Y. Y. 2000. Fumigation with nitric oxide to extend the postharvest life of strawberries. Postharvest Biol. Technol. 18:75-79.

Zhang, C., Wu, H., Li, X., Shi, H., Wei, F., and Zhu, G. 2013. Baseline sensitivity of natural populations and resistance of mutants of Xanthomonas oryzae pv. oryzae to a novel bactericide, zinc thiazole. Plant Pathol. 62:1378-1383.

Zimmermann, C., Hinrichs-Berger, J., Moltmann, E., and Buchenauer, H. 2004 Nested PCR (polymerase chain reaction) for detection of Xanthomonas fragariae in symptomless strawberry plants. J. Plant Dis. Prot. 111:39-51. 